\title{
In Vitro Ischemia Promotes Calcium Influx and Intracellular Calcium Release in Hippocampal Astrocytes
}

\author{
Steven Duffy and Brian A. MacVicar \\ Department of Neuroscience, University of Calgary, Calgary, Alberta, Canada T2N 4N1
}

The intracellular calcium concentration $\left(\left[\mathrm{Ca}^{2+}\right]_{i}\right)$ of astrocytes within rat hippocampal slices was measured during simultaneous hypoxia and hypoglycemia to examine the early intracellular signaling events induced by this in vitro model of ischemia. Hypoxia-hypoglycemia for 3.3-7.5 min evoked $\left[\mathrm{Ca}^{2+}\right]_{i}$ increases in astrocytes iontophoretically loaded with calcium orange (11/14 slices; $2.5 \mathrm{~min}$ to peak $\left[\mathrm{Ca}^{2+}\right]_{1}, 5 \mathrm{~min}$ to $>60 \mathrm{~min}$ duration). Calcium elevations also were observed in the absence of extracellular calcium ([Ca $\left.\left.\mathrm{Ca}^{2+}\right]_{0}\right)(4 / 4$ slices), indicative of $\mathrm{Ca}^{2+}$ release from internal stores. Hypoxia-hypoglycemia depolarized astrocytes $(51 \pm 16 \mathrm{mV})$, suggesting additional contribution from voltage-gated $\mathrm{Ca}^{2+}$ influx. Depolarization of a similar magnitude $(51 \pm 4 \mathrm{mV})$ by $50 \mathrm{~mm}$ extracellular potassium $\left(\left[\mathrm{K}^{+}\right]_{o}\right)$ triggered $\left[\mathrm{Ca}^{2+}\right]_{i}$ increases (20/24 slices), which were blocked by removal of $\left[\mathrm{Ca}^{2+}\right]_{0}$ (8/8 slices) indicating that depolarization promoted $\mathrm{Ca}^{2+}$ influx. Voltage-gated $\mathrm{Ca}^{2+}$ influx and internal release were measured in acutely isolated astrocytes during in vitro ischemia to examine these processes in the absence of surrounding neurons. Hypoxia-hypoglycemia (7.5$34.0 \mathrm{~min}$ ) induced only modest, slow increases in the basal $\left[\mathrm{Ca}^{2+}\right]_{i}$ of Fura-2-loaded isolated astrocytes (average $12 \%$ increase in Fura-2 ratio $R_{340 / 380}$ after $10 \mathrm{~min}$ ) that were blocked by $\left[\mathrm{Ca}^{2+}\right]_{0}$ removal. Voltage-gated $\mathrm{Ca}^{2+}$ influx was still functional under ischemia, however, as $50 \mathrm{~mm}\left[\mathrm{~K}^{+}\right]_{\mathrm{o}}$ evoked $\left[\mathrm{Ca}^{2+}\right]_{\mathrm{i}}$ increases (14/14 cells, $\Delta R_{340 / 380}$ of $\left.48 \%\right)$ approximately equal to preischemic responses. Isolated neurons displayed large irreversible increases in basal $\left[\mathrm{Ca}^{2+}\right]_{\text {ifter }}$ a.5-6.5 min in vitro ischemia (10/12 cells; average $\Delta R_{340 / 380}$ of $\left.152 \%\right)$. The absence of significant basal $\left[\mathrm{Ca}^{2+}\right]_{i}$ increases in isolated astrocytes indicates that ischemia-induced $\mathrm{Ca}^{2+}$ influx and internal release in astrocytes within slices depend on signals released from neurons $\left(\mathrm{K}^{+}\right.$, neurotransmitters). Ischemic $\left[\mathrm{Ca}^{2+}\right]_{1}$ elevations may constitute a signaling mechanism for postischemic reactive responses.

Key words: astrocyte; ischemia; intracellular calcium; calcium orange; hippocampus; Ca channels; pyramidal neurons
Astrocytes express complex $\left[\mathrm{Ca}^{2+}\right]_{i}$ signaling properties (Finkbeiner, 1993), and the induction of $\left[\mathrm{Ca}^{2+}\right]_{i}$ signals by neurotransmitters and other messengers in the extracellular microenvironment could mediate a functional coupling of astrocyte physiology to neuronal activity. Direct evidence for $\left[\mathrm{Ca}^{2+}\right]_{\mathrm{i}}$-dependent neuron-to-glial communication, however, requires examination of astrocylic $\left[\mathrm{Ca}^{2+}\right]_{\mathrm{i}}$ responses during well defined physiological or pathological processes in intact tissue. Astroglial responses in several models of ischemia have been studied extensively and are characterized by a progressive series of morphological and biochemical alterations collectively referred to as reactive transformation (for reviews, see Lindsay, 1986; Reier, 1986; Kraig and Jaeger, 1990; Landis, 1994). Conversely, the intracellular signaling mechanisms that induce reactive responses remain obscure. Given the ubiquity of $\left[\mathrm{Ca}^{2+}\right]_{i}$ elevations as a physiological signaling mechanism, we tested for the presence of $\left[\mathrm{Ca}^{2+}\right]_{i}$ signals in the early response of hippocampal astrocytes to simultaneous hypoxia and hypoglycemia, a widely used in vitro model of ischemia. Astrocytes express high-threshold $\mathrm{Ca}^{2+}$ currents (MacVicar, 1984; Barres et al., 1989, 1990; Corvalan et al., 1990), and elevating $\left[\mathrm{K}^{+}\right]_{0}$ to levels observed during ischemia in vivo (Somjen, 1979; Hansen, 1985) evoked significant $\left[\mathrm{Ca}^{2+}\right]_{i}$ elevations in isolated

\footnotetext{
Received June 13, 1995; revised Sept. 1, 1995; accepted Sept. 12, 1995.

This reseatch was supported by the Medical Research Council (Canada) and an equipment grant from AHFMR. S.D. was supported by Alberta Heritage for Medical Research (AHFMR) and William H. Davies scholarships. B.A.M. is an AHFMR scientist and Ciba-Geigy chair for schizophrenia research.

Correspondence should be addressed to Dr. Brian A. MacVicar, Department of Neuroscience, University of Calgary, 3330 Hospital Drive N.W., Calgary, Alberta, Canada T2N 4N1.

Copyright (C) 1995 Society for Neuroscience $0270-6474 / 95 / 160071-11 \$ 05.00 / 0$
}

hippocampal astrocytes by promoting voltage-dependent influx (Duffy and MacVicar, 1994b). Therefore, we directly tested for the activation of voltage-gated $\mathrm{Ca}^{2+}$ influx by anoxic depolarization. Because ischemic tissue also releases many neurotransmitters and second messengers, which could mobilize $\mathrm{Ca}^{2+}$ from internal stores, we also tested for such $\mathrm{Ca}^{\text {p+ }}$ release during brief ischemic episodes.

In this study, we used two complementary approaches to study ischemic $\left[\mathrm{Ca}^{2+}\right]_{i}$ signals in astrocytes. Fluorometric $\left[\mathrm{Ca}^{2+}\right]_{i}$ measurements from astrocytes iontophoretically loaded with the $\mathrm{Ca}^{2+}$-indicator calcium orange within hippocampal slices were performed to study ischemic responses in intact tissue. Additionally, $\left[\mathrm{Ca}^{2+}\right]_{\mathrm{i}}$ of acutely isolated astrocytes and neurons was measured during in vitro ischemia to assess the intrinsic ischemic responses in these cell types. These results show that brief episodes of simultancous hypoxia and hypoglycemia induce $\left[\mathrm{Ca}^{2+}\right]_{i}$ elevations in astrocytes that are mediated by voltage-gated influx and internal release. The $\left[\mathrm{Ca}^{2+}\right]_{i}$ of acutely isolated astrocytes is much less sensitive to ischemia than astrocytes in intact tissue or isolated neurons, indicating that astroglial $\left[\mathrm{Ca}^{2+}\right]_{\mathrm{i}}$ responses in hippocampal slices are mediated primarily by extracellular messengers released during ischemia (e.g., $\left[\mathrm{K}^{+}\right]_{\mathrm{o}}$ accumulation, neurotransmitters).

Some results have appeared in abstract form (Duffy and MacVicar, 1993, 1994a).

\section{MATERIALS AND METHODS}

Preparation and maintenance of hippocampal slices. Transverse hippocampal slices $(450 \mu \mathrm{m})$ from P21-P42 Sprague-Dawley rats were prepared using a manual tissue chopper (Stoelting) in artificial cerebrospinal fluid (aCSF) containing (in $\mathrm{mm}$ ): $124 \mathrm{NaCl}, 5 \mathrm{KCl}, 26$ 

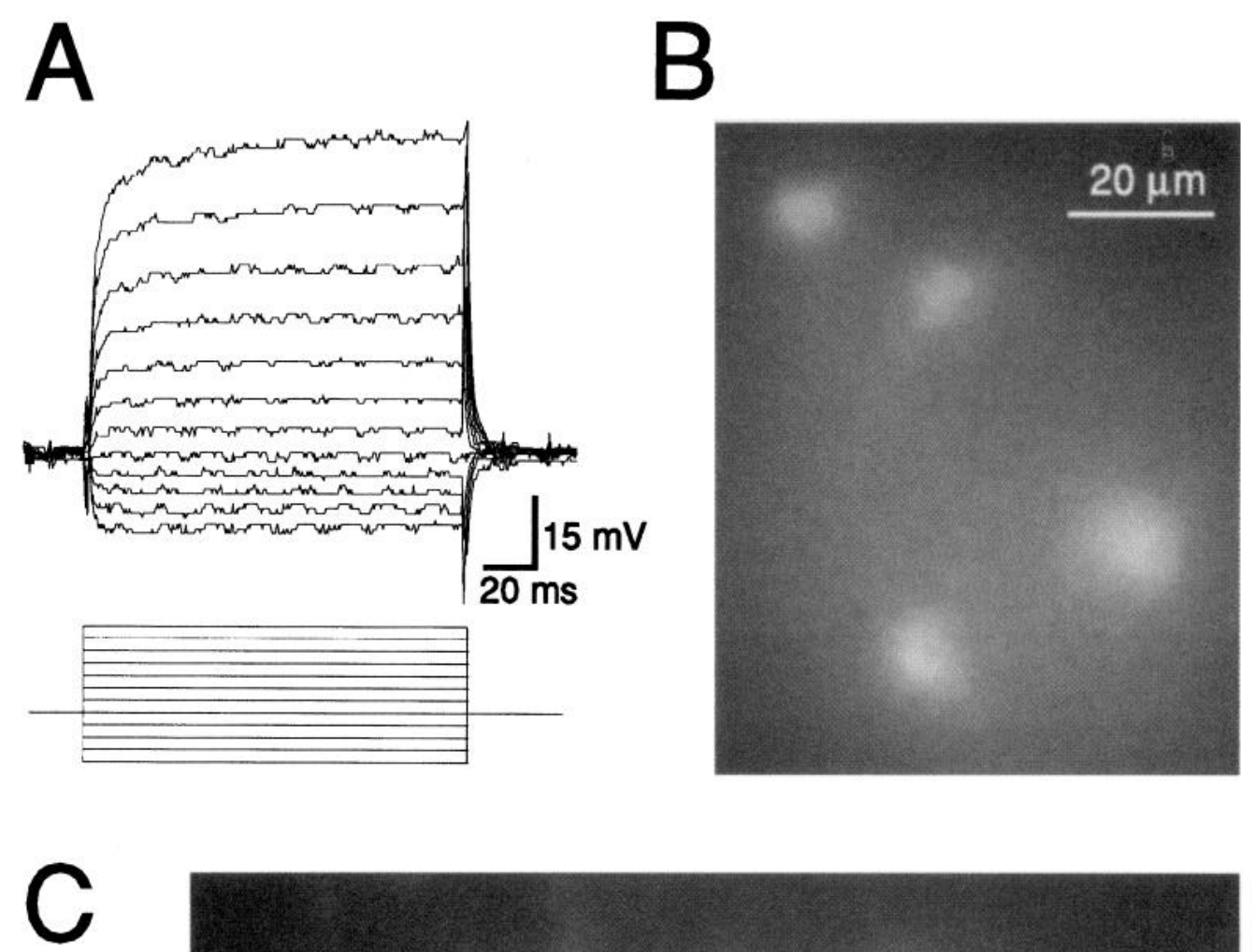

Figure 1. Iontophoretic injection of calcium orange into a single astrocyte resulted in the dye loading of many cells. $A$, The current-voltage relationship for an astrocyte impaled with a dye-filled electrode. No stimulusevoked action potentials were observed in response to $140 \mathrm{msec}$ current pulses between -0.8 and $1.4 \mathrm{nA}$. B, Fluorescence emission image at $580 \mathrm{~nm}$ showing the intracellular staining pattern after injection of the cell in $A$. Only a subfield of the injected cells is shown. $C$, A lower magnification image from another slice, demonstrating the full extent of dye coupling that resulted from $\sim 20 \mathrm{~min}$ injection of calcium or-

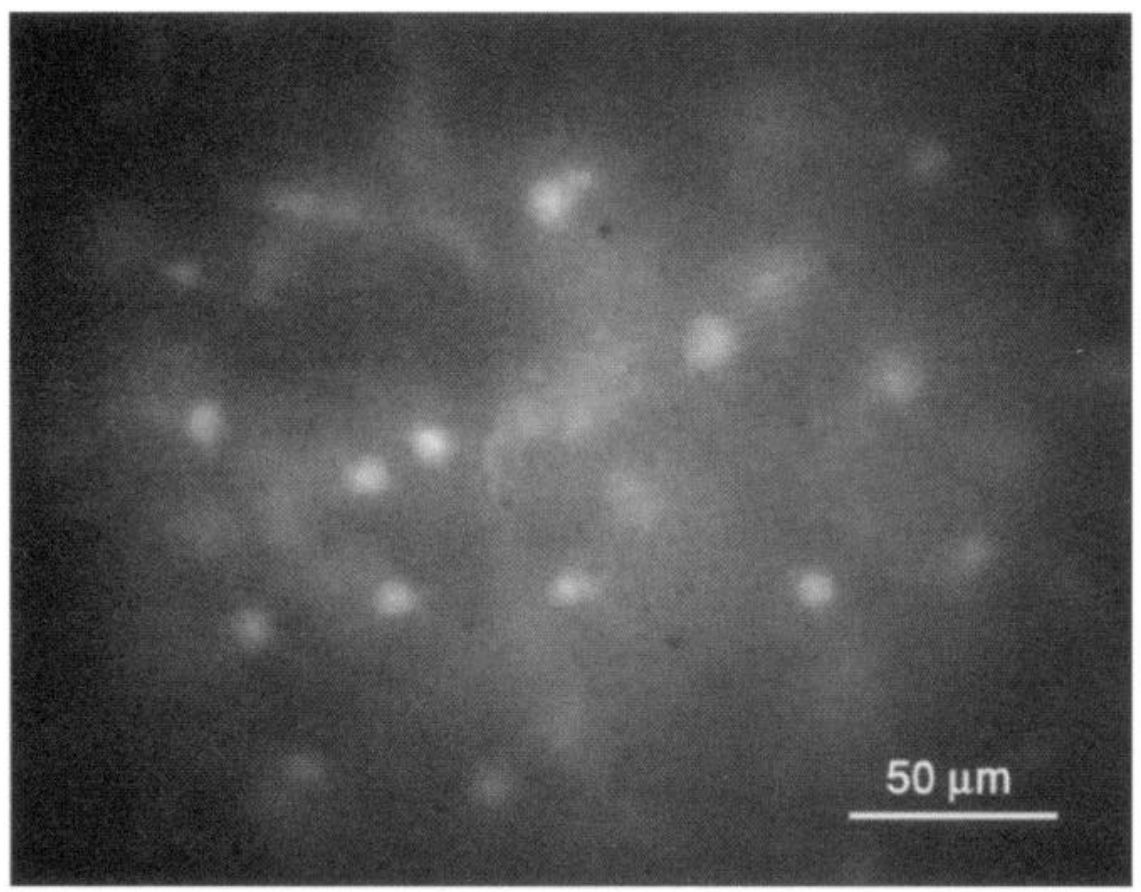
ange into a single astrocyte.

$\mathrm{NaHCO}_{3}, 1.3 \mathrm{MgCl}_{2}, 2 \mathrm{CaCl}_{2}, 10$ glucose; $\mathrm{pH}=7.35-7.40$. Slices were stored on filter paper saturated with aCSF in an aerated $\left(95 \% \mathrm{O}_{2} / 5 \%\right.$ $\mathrm{CO}_{2}$ ) interface chamber. For $\left[\mathrm{Ca}^{2+}\right]_{i}$ imaging experiments, individual slices were transferred to a submerged perfusion bath on the stage of an inverted epifluorescence microscope (Axiovert 10, Zeiss). Slices were superfused with aCSF at a rate of $0.5-0.6 \mathrm{ml} / \mathrm{min}$ using a peristaltic pump (Gilson). Calcium-free aCSF was prepared by omitting $\mathrm{CaCl}_{2}$ and adding $40-100 \mu \mathrm{M}$ of the $\mathrm{Ca}^{2+}$ chelator ethylene glycol bis( $\beta$-aminoethyl)ether- $N, N, N^{\prime}, N^{\prime}$-tetra-acetic acid (EGTA). For high $(50 \mathrm{~mm})\left[\mathrm{K}^{+}\right]_{\mathrm{o}}$ aCSF, $45 \mathrm{~mm} \mathrm{KCl}$ was substituted for $\mathrm{NaCl}$. Hypoxia and hypoglycemia were initiated by superfusing slices with glucose-free aCSF deoxygenated with $95 \% \mathrm{~N}_{2} / 5 \% \mathrm{CO}_{2}$ at $35 \pm 1^{\circ} \mathrm{C}$. All solutions contained 10 or $20 \mu \mathrm{M}$ of the heavy metal chelator tetrakis(2-pyridylmethyl)ethylenediamine (TPEN) (Arslan et al., 1985).

Iontophoretic loading of calcium orange and imaging of hippocampal astrocytes. The techniques for iontophoretic loading of astrocytes with calcium orange were described in detail previously (Duffy and MacVicar,
1995). Briefly, a microelectrode was filled with $100 \mathrm{~mm} \mathrm{~K}$ acetate plus 5 $\mathrm{mm}$ calcium orange, tetrapotassium salt (final electrode resistance: 75 $150 \mathrm{M} \Omega$ ) and mounted to the head stage of a physiological amplifier (Neurodata). Astrocytes 30-100 $\mu \mathrm{m}$ below the top cut surface were impaled, and hyperpolarizing current $(-0.2$ to $-0.5 \mathrm{nA})$ with superimposed square current pulses $(-0.4$ to $-1.0 \mathrm{nA}, 200-500 \mathrm{msec}$ duration, 1 $\mathrm{Hz}$ ) was passed through the electrode. Dye injection was continued as long as electrode resistance and membrane potential remained stable $(10-30 \mathrm{~min})$. For recording changes in astroglial membrane potential in response to $50 \mathrm{~mm}\left[\mathrm{~K}^{+}\right]_{\mathrm{o}}$ aCSF or during hypoxia-hypoglycemia, cells were impaled with lower-resistance electrodes (30-50 M $\Omega$ ) containing 2 $\mathrm{M} \mathrm{K}$ acetate or $1 \mathrm{M} \mathrm{KCl}$.

After injection, the slice was turned over so that loaded cells were within working distance of the objective $(50 \times$ Achroplan or $25 \times$ PlanNeofluar, Zeiss), and the slice was secured with small pieces of platinum wire. Excitation light from a $75 \mathrm{~W}$ Xenon arc lamp (Zeiss) was gated by an electronic shutter (Uniblitz T-132) controlled by Axon Imaging Work- 

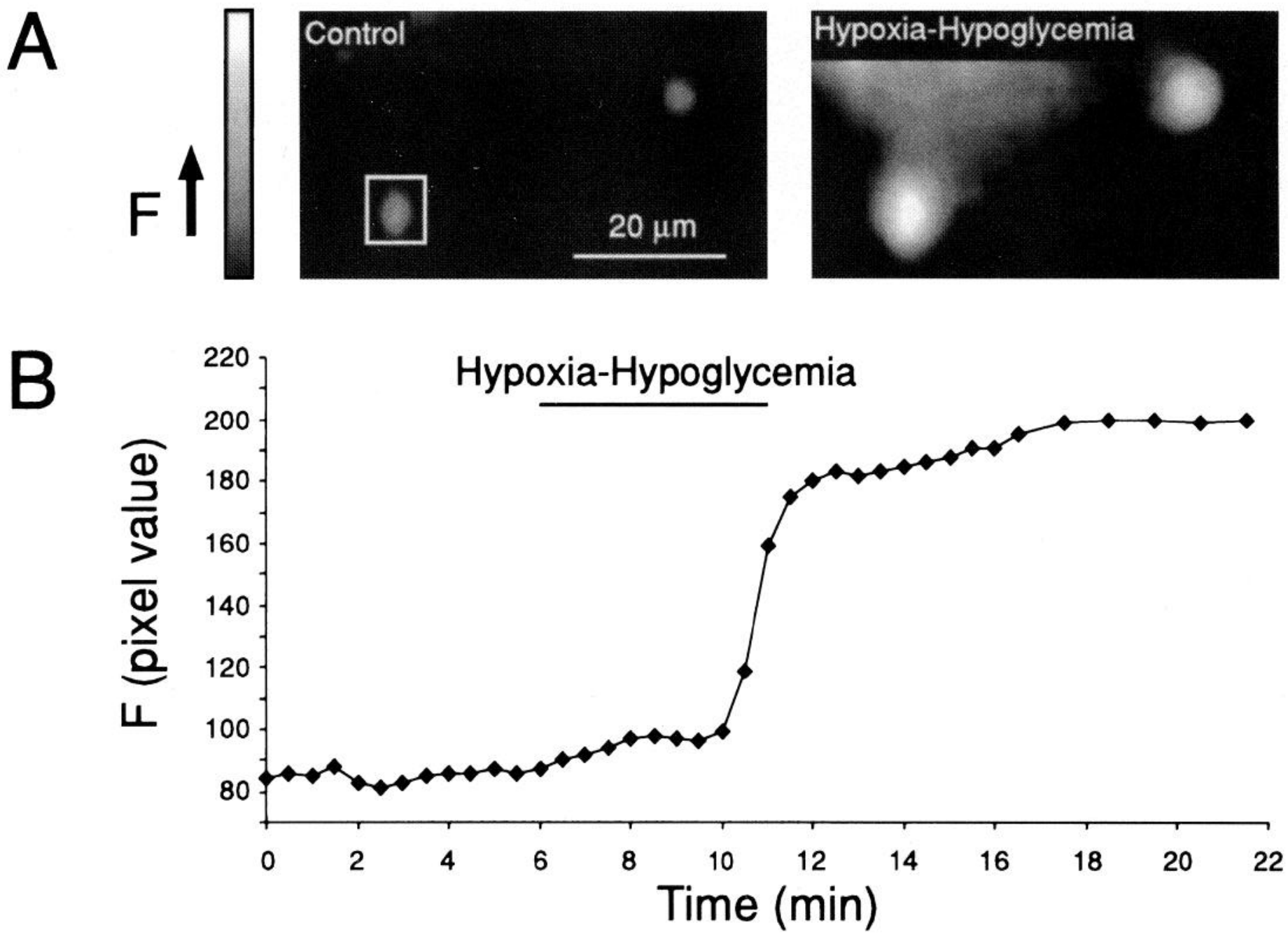

Figure 2. Simultaneous hypoxia-hypoglycemia induced an increase in astroglial $\left[\mathrm{Ca}^{2+}\right]_{\mathrm{i}} . A$, In response to 5 min superfusion of glucose-free aCSF aerated with $95 \% \mathrm{~N}_{2} / 5 \% \mathrm{CO}_{2}$, an increase in calcium orange fluorescence emission $(F)$ was observed, as indicated by increased brightness of the gray scale. Two astrocytes at the periphery of a cluster of dye-loaded cells are shown. $B$, The time course of the initial rise in $\Delta F$ for the cell demarcated by the box in $A$.

bench software (Axon Instruments). Rhodamine filters (Omega Optical) with excitation and emission maxima at $\sim 550$ and $580 \mathrm{~nm}$ were used to visualize fluorescence of the rhodamine-based dye calcium orange. Video images of calcium orange fluorescence emission $\left(F_{580}\right.$ or $\left.\Delta F_{580}\right)$ were recorded using a Cohu $6500 \mathrm{CCD}$ camera coupled to an image intensifier (KS-1381, Video Scope). Video frames were digitized and averaged (32 video frames/image) using an eight-bit A/D board (DT 2867, Data Translation) controlled by Axon Imaging Workbench software on a 486 microcomputer (Atman). Acquisition rates ranged from one image every 10-30 sec. Changes in $F_{580}$ were quantified by averaging the eight-bit pixel values (between 0 and 255) within a box overlapping an image of the astrocyte cell body. Because calcium orange is a nonratiometric dye with a narrow dynamic range (approximately four- to fivefold increase in $F_{580}$ from 0 to $39.8 \mu \mathrm{M}\left[\mathrm{Ca}^{2+}\right]$, Molecular Probes Handbook of Fluorescent Probes and Research Chemicals 1994), fluorescence measurements were not calibrated for absolute or relative changes in $\left[\mathrm{Ca}^{2+}\right]_{\mathrm{i}}$. A slow decrease in baseline fluorescence was observed in many experiments presumably because of continuous diffusion of dye through gap junctions into surrounding astrocytes (Duffy and MacVicar, 1995). For accurate determination of response duration, this decrease was compensated by a linear extrapolation:

$$
\Delta F=\left\{\left[-\left(F_{n}-F_{1}\right) /\left(t_{n}-t_{1}\right)\right] t_{i}+F_{i}\right\}-F_{1},
$$

where $F_{i}$ is the uncorrected fluorescence at time $t_{i}$, and $F_{1}$ and $F_{n}$ are the first and last $F$ values at times $t_{1}$ and $t_{n}$.
Intracellular calcium measurements from acutely isolated astrocytes and neurons. Astrocytes and neurons were acutely isolated as described previously (Duffy and MacVicar, 1994b), with a few modifications. Hippocampal slices $(500 \mu \mathrm{m})$ were prepared and incubated for 1-2 $\mathrm{hr}$ in control aCSF. Slices were placed on nylon mesh at the liquid-gas interface in an aerated $\left(95 \% \quad \mathrm{O}_{2} / 5 \% \mathrm{CO}_{2}\right)$ interface chamber. The chamber well contained $20 \mathrm{ml}$ of aCSF plus $2 \mathrm{mg} / \mathrm{ml}$ of the protease papain, $0.24 \mathrm{mg} / \mathrm{ml}$ of the papain activator L-cysteine, and $1 \mathrm{~mm}$ of the glutamate receptor antagonist kynurenic acid. The enzyme solution was stirred using a magnetic stirrer (Bellco) for $1 \mathrm{hr}$ at $32^{\circ} \mathrm{C}$. After digestion, slices were washed several times in aCSF. The CA1-CA 3 regions from two or three enzyme-treated slices were dissected free using a scalpel blade, and these sections were added to Dulbecco's Modified Eagle's Medium containing $16.6 \mu \mathrm{M}$ Fura-2 AM, predissolved in dimethyl sulfoxide (DMSO) with $10 \%$ pluronic acid, plus $1 \mathrm{~mm}$ kynurenic acid. Hippocampal cells were acutely isolated by repeated passage of tissue through fire-polished glass pipettes. The resultant cell suspension was allowed to settle for $\sim 20 \mathrm{~min}$ on poly-L-lysine-coated coverslips. Cells were superfused with aCSF containing $40 \mathrm{~mm}$ sucrose at 35 $\pm 1^{\circ} \mathrm{C}$. Hypoxic-hypoglycemic conditions were initiated as described for hippocampal slice experiments. Calcium imaging methodology was similar to that used for calcium orange experiments, except Fura-2 excitation filters $(340,360,380 \mathrm{~nm}$; Omega Optical) were mounted on a Lambda-10 rotating filter changer (Sutter Instruments) interposed between the shutter and the microscope. 


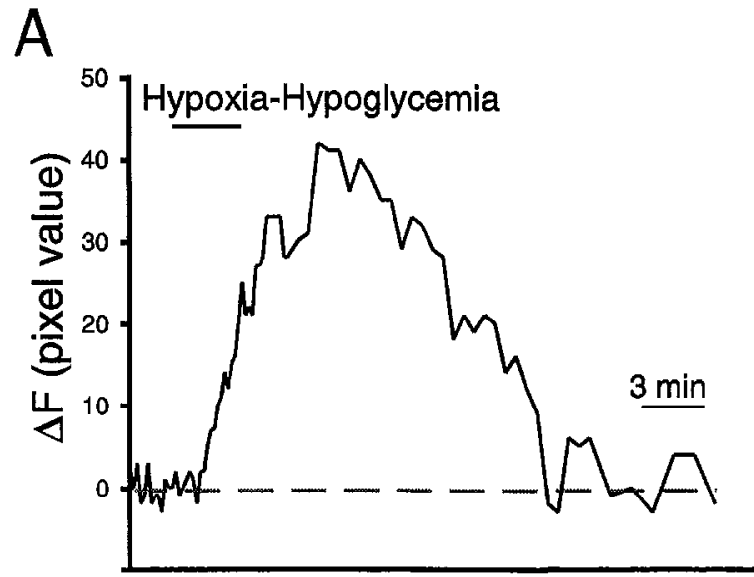

B

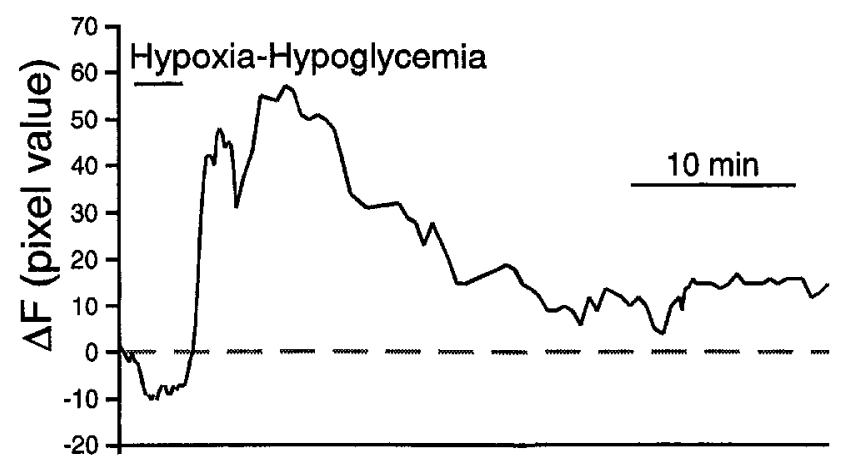

Figure 3. Variability in the duration of $\left[\mathrm{Ca}^{2+}\right]_{i}$ elevations produced by hypoxia-hypoglycemia. $A$, A 3.3 min episode evoked a reversible increase of $\sim 17$ min duration, whereas in another slice $(B)$ an episode of the same duration produced a maintained increase $(>40 \mathrm{~min})$.

\section{RESULTS}

\section{Effect of simultaneous hypoxia and hypoglycemia on astrocyte intracellular calcium}

Astrocytes in CA1-CA3 stratum radiatum were identified by their characteristic membrane potential $(75 \pm 3 \mathrm{mV}, n=36)$, absence of impalement- or stimulus-evoked action potentials (Fig. 1A), and extensive dye-coupling after 10-30 min ionotophoretic injcction of calcium orange (Fig. $1 B, C$ ). To examine the effects of ischemia on astrocyte $\left[\mathrm{Ca}^{2+}\right]_{i}$, microfluorometric $\left[\mathrm{Ca}^{2+}\right]_{i}$ measurements were performed during superfusion of glucose-free aCSF deoxygenated with $95 \% \mathrm{~N}_{2} / 5 \% \mathrm{CO}_{2}$. Under these hypoxichypoglycemic conditions, an increase in calcium orange fluorescence, indicating an increase in $\left[\mathrm{Ca}^{2+}\right]_{i}$, was observed in most slices within $7.5 \mathrm{~min}(n=11 / 14)$. A typical experiment is shown in Figure 2. After $5 \mathrm{~min}$ of hypoxia-hypoglycemia, a sudden rise in fluorescence emission was observed. The duration of hypoxiahypoglycemia required to initiate these $\left[\mathrm{Ca}^{2+}\right]_{i}$ increases ranged from 3.3 to $7.5 \mathrm{~min}(5.5 \pm 1.4 \mathrm{~min})$, after which $\left[\mathrm{Ca}^{2+}\right]_{i}$ rose to a peak within 1.5 to $4 \mathrm{~min}$ (average $2.5 \mathrm{~min}$ ).

After reoxygenation, $\left[\mathrm{Ca}^{2+}\right]_{\mathrm{i}}$ remained elevated for a highly variable period of time. The shorter $\left[\mathrm{Ca}^{2+}\right]_{i}$ elevations ranged from 5 to $17 \mathrm{~min}$ in duration (5/11 slices, Fig. $3 A$ ). The remaining responses were much longer, lasting at least $30-60 \mathrm{~min}$ (Fig. $3 B$ ). We could not accurately determine the exact duration of these longer $\left[\mathrm{Ca}^{2+}\right]_{i}$ responses because of uncertainty in extrapolating the baseline shift over long intervals (see Materials and Methods).
Response duration was inversely related to the ischemic episode required to evoke a $\left[\mathrm{Ca}^{2+}\right]_{\mathrm{i}}$ signal. The minimum ischemic period required was $4.6 \pm 0.7 \mathrm{~min}$ (range, $3.3-5.5 \mathrm{~min}$ ), for the longest responses $(17 \mathrm{~min}$ to $>1 \mathrm{hr}$ ), compared with $7.0 \pm 0.6 \mathrm{~min}$ for the shortest (4.0-7.5 $\mathrm{min}$ ) responses. A minority of the slices tested (3/14) were unresponsive to $10 \mathrm{~min}$ of hypoxia-hypoglycemia (the longest duration tested).

\section{The role of calcium release from intracellular stores}

To examine the source of this $\left[\mathrm{Ca}^{2+}\right]_{\mathrm{i}}$ elevation, we first examined the dependence on $\left[\mathrm{Ca}^{2+}\right]_{0} . \wedge\left[\mathrm{Ca}^{2+}\right]_{i}$ increase was still observed in response to hypoxia-hypoglycemia after washout of extracellular calcium (Fig. 4, six responses in four slices). Unlike $\left[\mathrm{Ca}^{2+}\right]_{i}$ increases in the presence of $\left[\mathrm{Ca}^{2+}\right]_{0}$, these responses were always brief (mean duration, $16.8 \mathrm{~min}$ ) and of relatively constant duration (range, 16.5-17.5 $\mathrm{min}$ ). A second ischemic episode in 0 $\left[\mathrm{Ca}^{2+}\right]_{0}$ also induced a $\left[\mathrm{Ca}^{2+}\right]_{\mathrm{i}}$ increase $(n=2 / 2 ; 13.5$ and 12.25 min).

\section{The role of voltage-dependent calcium influx}

Intracellular recordings in hippocampal slices from astrocytes, which were not dye-loaded, revealed a depolarization in response to hypoxia and hypoglycemia (Fig. 5; peak $\Delta E_{m}=51 \pm 16 \mathrm{mV}$, range, $30-70 \mathrm{mV}, n=9$ ). This measurement of peak depolarization underestimated the true value, however, because electrode penetration usually was lost during the most rapid phase of depolarization probably because of tissue swelling (Andrew and MacVicar, 1994)

The observation that hypoxia-hypoglycemia both depolarized astrocytes and increased $\left[\mathrm{Ca}^{2+}\right]_{i}$ suggested that another mechanism mediating these responses was influx through voltage-gated Ca channels (Duffy and MacVicar, 1994b). This putative ischemia-induced $\mathrm{Ca}^{2+}$ influx could not be isolated from the total $\left[\mathrm{Ca}^{2+}\right]_{\mathrm{i}}$ response because this would require either specific blockade of astroglial internal $\mathrm{Ca}^{2+}$ stores or quantitative comparison of responses in the presence and absence of $\left[\mathrm{Ca}^{2+}\right]_{0}$. This later option was not possible using the nonratiometric calcium orange, and iontophoretic injection of Fura-2 did not yield satisfactory resolution of individual astrocytes over background autofluorescence. Thus, ischemic $\mathrm{Ca}^{2+}$ influx was studied indirectly, first by establishing the presence of voltage-dependent $\mathrm{Ca}^{2+}$ influx in astrocytes under normoxic conditions and subsequently by demonstrating that such influx is opcrational under ischemia.

To investigate the role of voltage-gated $\mathrm{Ca}^{2+}$ influx independently from other putative ischemia-specific $\left[\mathrm{Ca}^{2+}\right]_{i}$ mobilizing pathways, we first measured $E_{m}$ and $\left[\mathrm{Ca}^{2+}\right]_{\mathrm{i}}$ during elevation of $\left[\mathrm{K}^{+}\right]_{\mathrm{o}}$ under normoxic conditions. Increasing the $\left[\mathrm{K}^{+}\right]_{\mathrm{o}}$ from 5 to $50 \mathrm{mM}$ for 3 or $4 \mathrm{~min}$ depolarized astrocytes by $51 \pm 4 \mathrm{mV}$ (average of eight cells at $22-24^{\circ} \mathrm{C}$ ). In dye-loaded slices, superfusion of $50 \mathrm{~mm}\left[\mathrm{~K}^{+}\right]_{\mathrm{o}}$ aCSF also caused a $\left[\mathrm{Ca}^{2+}\right]_{\mathrm{i}}$ increase in astrocytes (20 of 24 slices, Fig. 6). In those slices that showed a $\left[\mathrm{Ca}^{2+}\right]_{\mathrm{i}}$ increase (80\% of slices tested), such $\left[\mathrm{Ca}^{2+}\right]_{\mathrm{i}}$ signals were observed in all visible astrocytes (66/66 cells from 20 slices). These increases followed a nearly synchronous time course in neighboring cells (19/20 slices, 61/66 cells). Responses were never observed after removal of $\left[\mathrm{Ca}^{2+}\right]_{o}$ (Fig. $6 A ; 0 / 5$ slices at $22-24^{\circ} \mathrm{C}, 0 / 3$ slices at $\left.35 \pm 1^{\circ} \mathrm{C}\right)$. 'I'he $\mathrm{Ca}$ channel blocker verapamil $(70 \mu \mathrm{M})$, which blocks voltage-dependent $\mathrm{Ca}^{2+}$ influx in acutely isolated astrocytcs (Duffy and MacVicar, 1994b), also inhibitcd $\left[\mathrm{Ca}^{2+}\right]_{i}$ clcvations induced by $50 \mathrm{~mm}\left[\mathrm{~K}^{+}\right]_{0}$ in astrocytes within slices $(n=5 / 5$ slices, data not shown). In contrast, elevation of $\left[\mathrm{K}^{+}\right]_{0}$ to $15 \mathrm{~mm}$ (4-7 min), which corresponds to the ceiling $\left[\mathrm{K}^{+}\right]_{\mathrm{o}}$ increases ob- 
$\ln 0\left[\mathrm{Ca}^{2+}\right]_{0}$

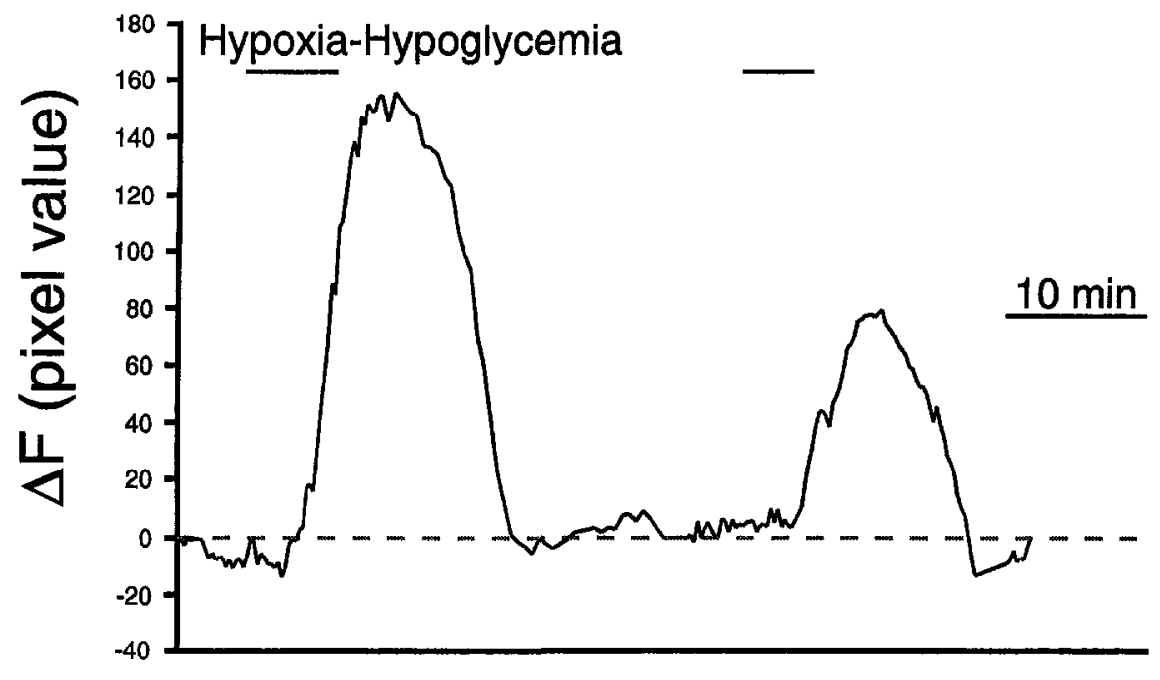

Figure 4. Two episodes of hypoxia-hypoglycemia $(6.5$ and $5.0 \mathrm{~min})$ induced $\left[\mathrm{Ca}^{2+}\right]_{\mathrm{i}}$ increases in the absence of $\left[\mathrm{Ca}^{2+}\right]_{0}$. served in situ during intense neuronal activity, did not increase $\left[\mathrm{Ca}^{2+}\right]_{\mathrm{i}}$ (Fig. 6B). Rather, a transient decrease in calcium orange fluorescence was observed, likely reflecting dilution of dye concentration concomitant with $\left[\mathrm{K}^{+}\right]_{\mathrm{o}}$-dependent astroglial swelling (Walz, 1989). In all cases, subsequent application of $50 \mathrm{~mm}\left[\mathrm{~K}^{+}\right]_{\circ}$ did induce a response $\left(n=6 / 6\right.$ slices, $n=4 / 4$ at $22-24^{\circ} \mathrm{C}, n=2 / 2$ at $35 \pm 1^{\circ} \mathrm{C}$ ). Response duration was markedly temperaturesensitive; at $35 \pm 1^{\circ} \mathrm{C}, 2.5-3.0 \mathrm{~min}$ of $50 \mathrm{~mm}\left[\mathrm{~K}^{+}\right]_{\mathrm{o}}$ evoked $\left[\mathrm{Ca}^{2+}\right]_{\mathrm{i}}$ increases $>35 \mathrm{~min}$ in duration (Fig. $6 \mathrm{~A}, n=3 / 3$ ), whereas $4 \mathrm{~min}$ of $50 \mathrm{~mm}\left[\mathrm{~K}^{+}\right]_{\mathrm{o}}$ at $22-24^{\circ} \mathrm{C}$ triggered biphasic $\left[\mathrm{Ca}^{2+}\right]_{\mathrm{i}}$ increases lasting $13.65 \pm 4.05 \mathrm{~min}$ (Fig. $6 B, n=5$ ).

Anoxic depolarization and normoxic spreading depression cause astrocyte volume increases (Walz, 1989; Landis, 1994), and this response can promote $\mathrm{Ca}^{2+}$ influx into cultured glia by activating stretch-sensitive Ca channels (Puro, 1991). To determine whether cell swelling in the absence of depolarization can influence $\left[\mathrm{Ca}^{2+}\right]_{i}$ in hippocampal astrocytes that have not been cultured, hypo-osmotic aCSF ( -60 to $-120 \mathrm{mOsm}$ ) was superfused onto dye-loaded slices.
In response to 3-5 min of hypo-osmolar aCSF, $\left[\mathrm{Ca}^{2+}\right]_{i}$ did not increase; rather, a decrease in fluorescence emission was observed (Fig. $7 ; n=5 / 5$ ) possibly because of dilution of the intracellular dye concomitant with the cell volume increase.

\section{Ischemic responses in acutely isolated astrocytes and neurons}

Because in vitro ischemia and $\left[\mathrm{K}^{+}\right]_{0}$ elevation in intact tissue depolarize both astrocytes and neurons, it is difficult to differentiate the direct effect of depolarization on astroglial $\left[\mathrm{Ca}^{2+}\right]_{i}$ from effects mediated by signals (i.e., neurotransmitters) released from adjacent neurons. We therefore measured ischemic $\left[\mathrm{Ca}^{2+}\right]_{i}$ responses in acutely isolated astrocytes and neurons. In contrast to the rapid $\left[\mathrm{Ca}^{2+}\right]_{\mathrm{i}}$ elevations evoked in astrocytes within brain slices, hypoxia-hypoglycemia triggered slowly developing increases in the basal $\left[\mathrm{Ca}^{2+}\right]_{\mathrm{i}}$ of acutely isolated astrocytes (Fig. 8). The average increase in Fura- 2 ratio $R_{340 / 380}$ was $6 \%$ after 5 min, $12 \%$ after $10 \mathrm{~min}$, and $15 \%$ after $12-15 \mathrm{~min}$ continuous in vitro



Figure 5. Hypoxia-hypoglycemia depolarized astroglia within hippocampal slices. Ten minutes of hypoxia-hypoglycemia induced a large depolarization, which was approximately equivalent in magnitude to a depolarization evoked by subsequent addition of 50 $\mathrm{mm}\left[\mathrm{K}^{+}\right]_{\circ}$. 
A

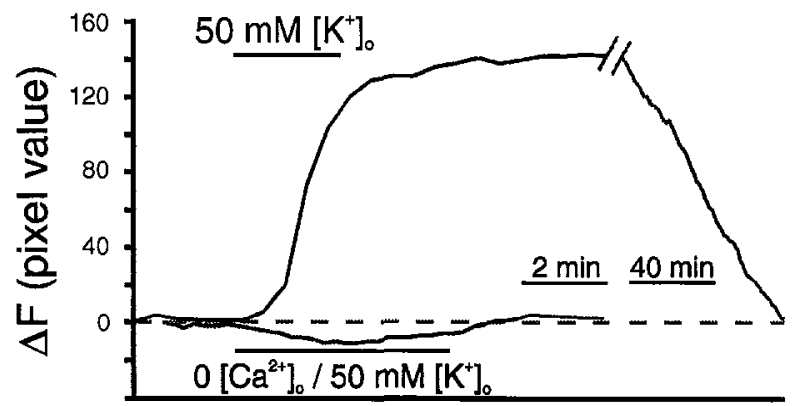

B

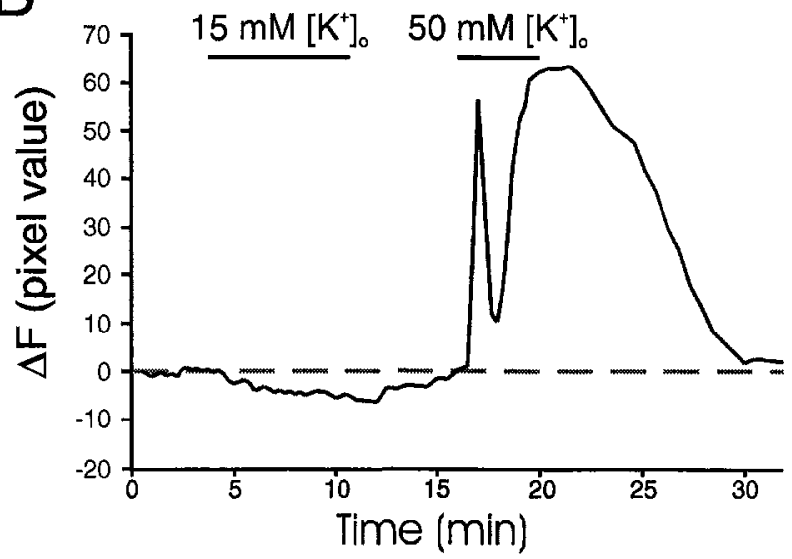

Figure 6. Elevating $\left[\mathrm{K}^{+}\right]_{\mathrm{o}}$ from $5 \mathrm{mM}$ to $50 \mathrm{~mm}$ increased astrocyte $\left[\mathrm{Ca}^{2+}\right]_{\mathrm{i}} . A$, In response to $3 \mathrm{~min}$ superfusion of $50 \mathrm{mM}\left[\mathrm{K}^{+}\right]_{\mathrm{o}}$, a $\left[\mathrm{Ca}^{2+}\right]_{\mathrm{i}}$ increase was observed in $2 \mathrm{mM}\left[\mathrm{Ca}^{2+}\right]_{0}$ (top), but not in $\left[\mathrm{Ca}^{2+}\right]_{0}$-free saline (bottom). $T=35^{\circ} \mathrm{C} . B$, Superfusion of $15 \mathrm{~mm}\left[\mathrm{~K}^{+}\right]_{\mathrm{o}}$ for $7 \mathrm{~min}$ did not increase $\left[\mathrm{Ca}^{2+}\right]_{\mathrm{i}}$; rather, a modest fluorescence decrease was observed. Subsequent addition of $50 \mathrm{~mm}\left[\mathrm{~K}^{+}\right]_{\mathrm{o}}$ for 4 min caused a $\left[\mathrm{Ca}^{2+}\right]_{\mathrm{i}}$ increase $\left(T=22^{\circ} \mathrm{C}\right)$.

ischemia. This increase was completely reversible by removal of $\left[\mathrm{Ca}^{2+}\right]_{\mathrm{o}}$ (Fig. $8 A ; n=8 / 8$ cells), indicating that ischemia caused a small net increase in resting $\mathrm{Ca}^{2+}$ influx. Depolarization by $45-90$ sec superfusion of $50 \mathrm{~mm}\left[\mathrm{~K}^{+}\right]_{\mathrm{o}}$ during prolonged hypoxia-hypoglycemia (7.5-34 min) evoked more rapidly developing and larger $\left[\mathrm{Ca}^{2+}\right]_{\mathrm{i}}$ increases $(14 / 14$ cells; average $\Delta R$ of $48 \%)$, which were also blocked by $\left[\mathrm{Ca}^{2+}\right]_{0}$ removal ( $n=3 / 3$ cells; Fig. $8 B, C$ ). Average response magnitude was not significantly different from preischemic $\left[\mathrm{K}^{+}\right]_{0}$-evoked $\left[\mathrm{Ca}^{2+}\right]_{1}$ responses (average $\Delta R_{\text {ischemia }}$ $95 \%$ of control, $n=9$ cells). Astroglial Ca channels, therefore, are functional under ischemia, but significant $\mathrm{Ca}^{2+}$ influx requires additional depolarization.

In contrast to acutely isolated astrocytes, acutely isolated pyramidal neurons showed large, irreversible $\left[\mathrm{Ca}^{2+}\right]_{\mathrm{i}}$ responses after brief ( $1.5-6.5 \mathrm{~min}$ ) episodes of hypoxia-hypoglycemia ( $n=10 / 12$ cells, $\Delta R$ of $152 \%$ ), which were not reversed by removal of $\left[\mathrm{Ca}^{2+}\right]_{0}$ (Fig. 9; $n=5 / 5$ cells). These differences in the ischemic $\left[\mathrm{Ca}^{2+}\right]_{\mathrm{i}}$ responses of acutely isolated neurons, isolated astrocytes, and astrocytes within intact tissue are summarized in Figure 10. In some experiments, coisolated astrocytes and neurons within the same field of view (100-300 $\mu \mathrm{m}$ apart) wcrc imaged simultaneously during hypoxia-hypoglycemia. These experiments demonstrate the marked differences in intrinsic ischemic-sensitivity under identical conditions (Fig. 10A, $n=3$ ). Finally, in Figure
$10 B$, the ischemic response of an astrocyte within a slice is compared with an acutely isolated cell to demonstrate the dramatically different kinetics of the basal $\left[\mathrm{Ca}^{2+}\right]_{i}$ increase.

\section{DISCUSSION}

Brief episodes of simultaneous hypoxia and hypoglycemia, a common in vitro model of ischemia, increased $\left[\mathrm{Ca}^{2+}\right]_{\mathrm{i}}$ in rat hippocampal astrocytes by promoting voltage-dependent $\mathrm{Ca}^{2+}$ influx and $\mathrm{Ca}^{2+}$ release from internal stores. Intracellular calcium increases have been measured previously in cultured astrocytes during anoxia (Haun et al., 1992), but our results represent the first direct measurements of this response in intact tissue that has not been cultured. In cultured astrocytes, moreover, significant $\left[\mathrm{Ca}^{2+}\right]_{i}$ elevations and cellular dysfunction (possibly mediated by $\left[\mathrm{Ca}^{2+}\right]_{i}$ ) require many hours of continuous hypoxia and hypoglycemia ( $\mathrm{Yu}$ et al., 1989; Haun et al., 1992), although we report that $\left[\mathrm{Ca}^{2+}\right]_{i}$ signaling is a predominant component of the very early ischemic response. Similar to results in culture, acutely isolated astrocytes showed no significant increase in basal $\left[\mathrm{Ca}^{2+}\right]_{i}$ during brief hypoxia-hypoglycemia, indicating that extracellular messengers released from ischemic tissue stimulate these responses in intact brain.

\section{The mechanisms of astroglial $\left[\mathrm{Ca}^{2+}\right]_{i}$ increases during hypoxia-hypoglycemia}

Increases in $\left[\mathrm{Ca}^{2+}\right]_{\mathrm{i}}$ were induced by in vitro ischemia in the absence of $\left[\mathrm{Ca}^{2+}\right]_{0}$, indicative of $\mathrm{Ca}^{2+}$ release from internal stores. Whether this release was mediated by activation of receptors linked to inositol triphosphate production or by $\mathrm{Ca}^{2+}$ store disruption because of ATP depletion is uncertain. Ischemia could induce the release of a large number of transmitters or messengers, which mobilize $\mathrm{Ca}^{2+}$ stores in hippocampal astrocytes. Our observations that the transient $\left[\mathrm{Ca}^{2+}\right]_{0}$-independent responses observed in slices were not seen in isolated astrocytes suggest the influence of neurotransmitters or intercellular messengers, although the identity of these messengers is unknown. Glutamate is one obvious candidate, as ischemia is associated with large elevations in extracellular glutamate (Szatkowski and Attwell, 1994), but glutamate receptor agonists did not increase $\left[\mathrm{Ca}^{2+}\right]_{i}$ of astrocytes within hippocampal slices (Duffy and MacVicar, 1995). Alternatively, reductions in intracellular ATP also could result in rapid efflux of stored $\mathrm{Ca}^{2+}$ bccausc these stores are maintaincd by ATPase activity and the stored $\mathrm{Ca}^{2+}$ is in rapid equilibrium with the cytosol (Pozzan et al., 1994).

The observation that $\left[\mathrm{K}^{+}\right]_{\mathrm{o}}$ depolarization induced $\mathrm{Ca}^{2+}$ influx suggests that the ischemic depolarization also promotes influx. However, $\mathrm{Ca}^{2+}$ currents can be suppressed by anoxia (Krnjevic and Leblond, 1989; Young and Somjen, 1992), so we examined $\left[\mathrm{K}^{+}\right]_{\mathrm{o}}$-induced $\mathrm{Ca}^{2+}$ influx in isolated astrocytes in which pre- and postischemic $\left[\mathrm{Ca}^{2+}\right]_{i}$ could be quantified and compared. Under these conditions, significant $\left[\mathrm{Ca}^{2+}\right]_{\mathrm{i}}$ elevations were observed, but only upon $\left[\mathrm{K}^{+}\right]_{0}$ depolarization. This strongly suggests that $\mathrm{Ca}^{2+}$ influx in intact tissue is triggered by depolarization concomitant with deregulation of $\left[\mathrm{K}^{+}\right]$o rather than by an intrinsic depolarizing response. Other routes of $\mathrm{Ca}^{2+}$ influx also are possible. For example, reoxygenation could lead to the formation of free radicals, which promote $\mathrm{Ca}^{2+}$ release or inhibit $\left[\mathrm{Ca}^{2+}\right]_{\mathrm{i}}$ buffering. We also have shown that GABA promotes $\mathrm{Ca}^{2+}$ influx via $\mathrm{GABA}_{\mathrm{A}}$ receptor-mediated depolarization (Fraser et al., 1995), suggesting that nonglutamatergic transmitters may contribute to the observed $\left[\mathrm{Ca}^{2+}\right]_{\mathrm{i}}$ response. Alternatively, internal $\mathrm{Na}^{+}$accumulation 


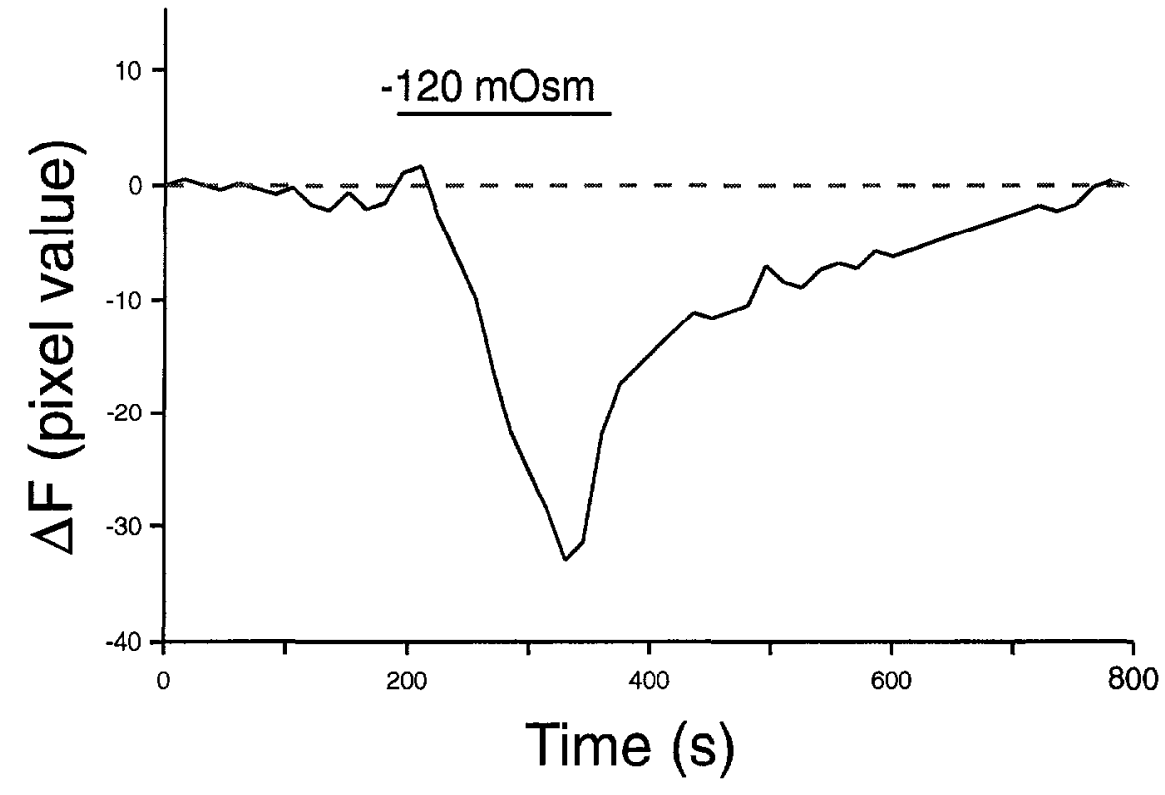

Figure 7. Hypo-osmotic aCSF did not increase $\left[\mathrm{Ca}^{2+}\right]_{i}$. Reducing the osmolarity from 290 to 170 mOsm caused a decrease in fluorescence emission $(\Delta F)$ could lead to $\mathrm{Ca}^{2+}$ influx through reversal of the $\mathrm{Na}^{+}-\mathrm{Ca}^{2+}$ exchange (Waxman et al., 1991; Kim-I ee et al., 1992).

\section{Ischemic $\left[\mathrm{Ca}^{2+}\right]_{i}$ increases in astrocytes versus neurons}

The electrophysiological and biochemical responses of neurons to ischemia have been documented extensively, and it is widely held that a sustained increase in $\left[\mathrm{Ca}^{2+}\right]_{\mathbf{i}}$ (so-called $\left[\mathrm{Ca}^{2+}\right]_{\mathbf{i}}$ deregulation) is one important factor mediating neuronal damage (for reviews, see Orrenius et al., 1989; Siesjo and Bengtsson 1989; Choi, 1990; Nicotera et al., 1992; Martin et al., 1994). However, many studies of neuronal $\left[\mathrm{Ca}^{2+}\right]_{i}$ during ischemia have measured $\left[\mathrm{Ca}^{2+}\right]_{\mathrm{i}}$ in tissue bulk-loaded with $\mathrm{Ca}^{2+}$ indicators. The results presented here indicate that these measurements probably include both a neuronal and an astroglial component. Moreover, these components are not easily separable because they share similar kinetics. For instance, the duration of in vitro ischemia required to induce astroglial $\left[\mathrm{Ca}^{2+}\right]_{\mathrm{i}}$ responses falls within the range that induces anoxic depolarizations (Clark and Rothman, 1987; Grigg and Anderson, 1990; Rader and Lanthorn, 1989) and $\left[\mathrm{Ca}^{2+}\right]_{\mathrm{i}}$ increases in neurons (Silver and Erecinska, 1990; Lobner and Lipton, 1993; Mitani et al., 1993). Moreover, ischemic $\left[\mathrm{Ca}^{2+}\right]_{\mathbf{i}}$ responses in both astrocytes (reported here) and neurons (Katchman and Hershkowitz, 1993; Lobner and Lipton, 1993; Mitani et al., 1993) involve $\mathrm{Ca}^{2+}$ influx and release from internal stores. The quantitative contribution made by astrocytes to the total tissue $\left[\mathrm{Ca}^{2+}\right]_{i}$ response would depend on the relative volume of the astroglial compartment. On average, astroglia comprise one-third of the cellular volume of gray matter (Pope, 1978). In areas such as the stratum radiatum, where neuronal somata are sparse, the contribution of astrocyte $\left[\mathrm{Ca}^{2+}\right]_{i}$ signals could be substantial.

Although both neurons and astrocytes display ischemic $\left[\mathrm{Ca}^{2+}\right]_{i}$ elevations, there are dramatic differences in postischemic viability. A few minutes of focal ischemia can trigger neuronal degeneration, whereas signiticant astroglial death requires many hours ( $\mathrm{Yu}$ et al., 1989; Haun et al., 1992). The viability of isolated neurons was not directly assessed in this study, although we noted a significant reduction in Fura-2 fluorescence 10-15 min after the initial $\left[\mathrm{Ca}^{2+}\right]_{\mathrm{i}}$ increase, suggesting loss of membrane integrity (our unpublished observations). Neither dye leakage nor irreversible
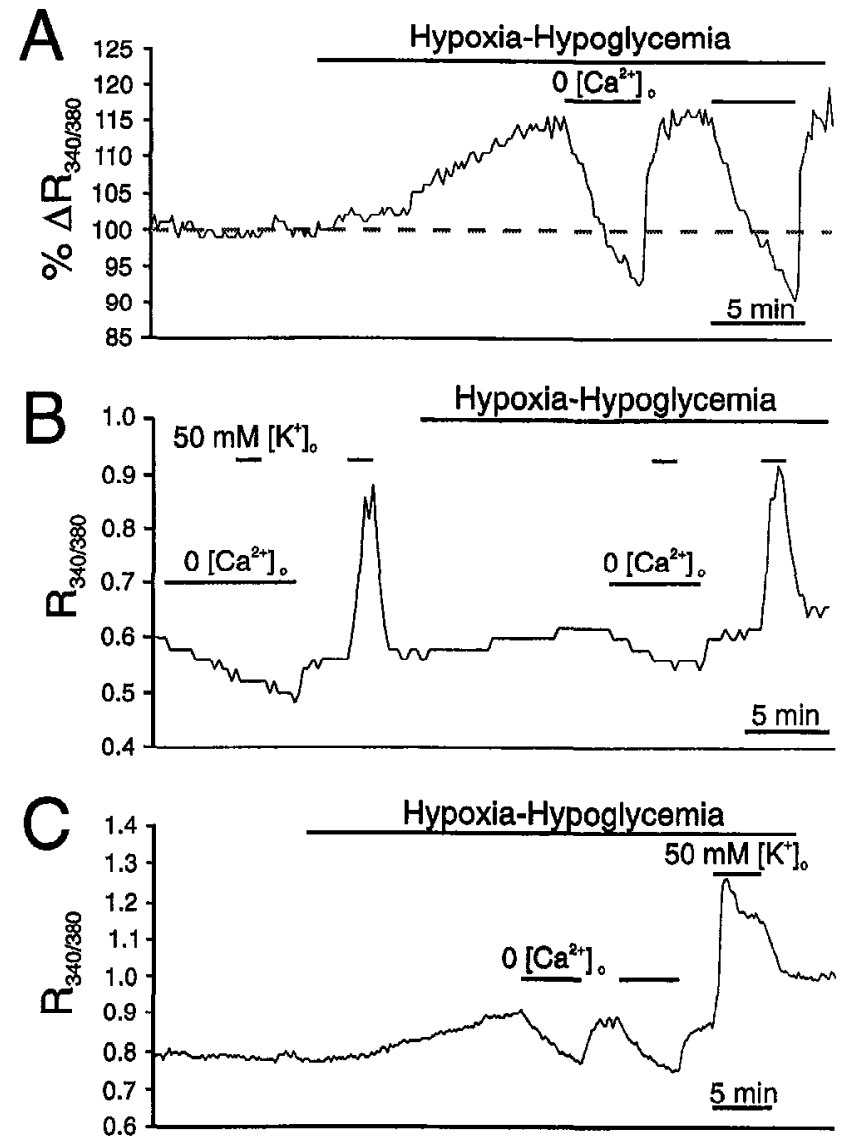

Figure 8. Effect of hypoxia-hypoglycemia on basal and $\left[\mathrm{K}^{+}\right]_{0}$-evoked $\left[\mathrm{Ca}^{2+}\right]_{\mathrm{i}}$ increases in acutely isolated astrocytes loaded with Fura-2. $A$, Hypoxia-hypoglycemia caused a modest increase in basal $\left[\mathrm{Ca}^{2+}\right]_{i}$, as revealed by the change in Fura- 2 ratio $R_{340 / 380}$ of $14 \%$ over $13 \mathrm{~min}$. This increase was reversed by $\left[\mathrm{Ca}^{2+}\right]$ removal. Subsequent readdition of $\left[\mathrm{Ca}^{2+}\right]_{0}$ resulted in re-elevation of $\left[\mathrm{Ca}^{2+}\right]_{\mathrm{i}} . B$, Superfusion of $50 \mathrm{mM}\left[\mathrm{K}^{+}\right]_{\mathrm{o}}$ increased $\left[\mathrm{Ca}^{2+}\right]_{i}$ under normoxic conditions and after 20 min of hypoxiahypoglycemia. No response was observed under either condition in the absence of $\left[\mathrm{Ca}^{2+}\right]_{\mathrm{o}} . C, 50 \mathrm{~mm}\left[\mathrm{~K}^{+}\right]_{\mathrm{o}}$ still elicited a $\left[\mathrm{Ca}^{2+}\right]_{\mathrm{i}}$ increase after prolonged (34 $\mathrm{min}$ ) hypoxia-hypoglycemia. 
A

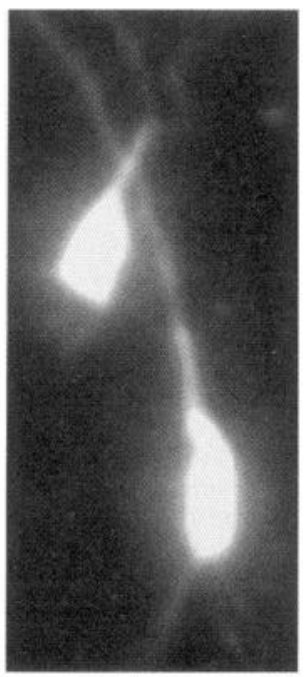

B

\section{Hypoxia-Hypoglycemia}

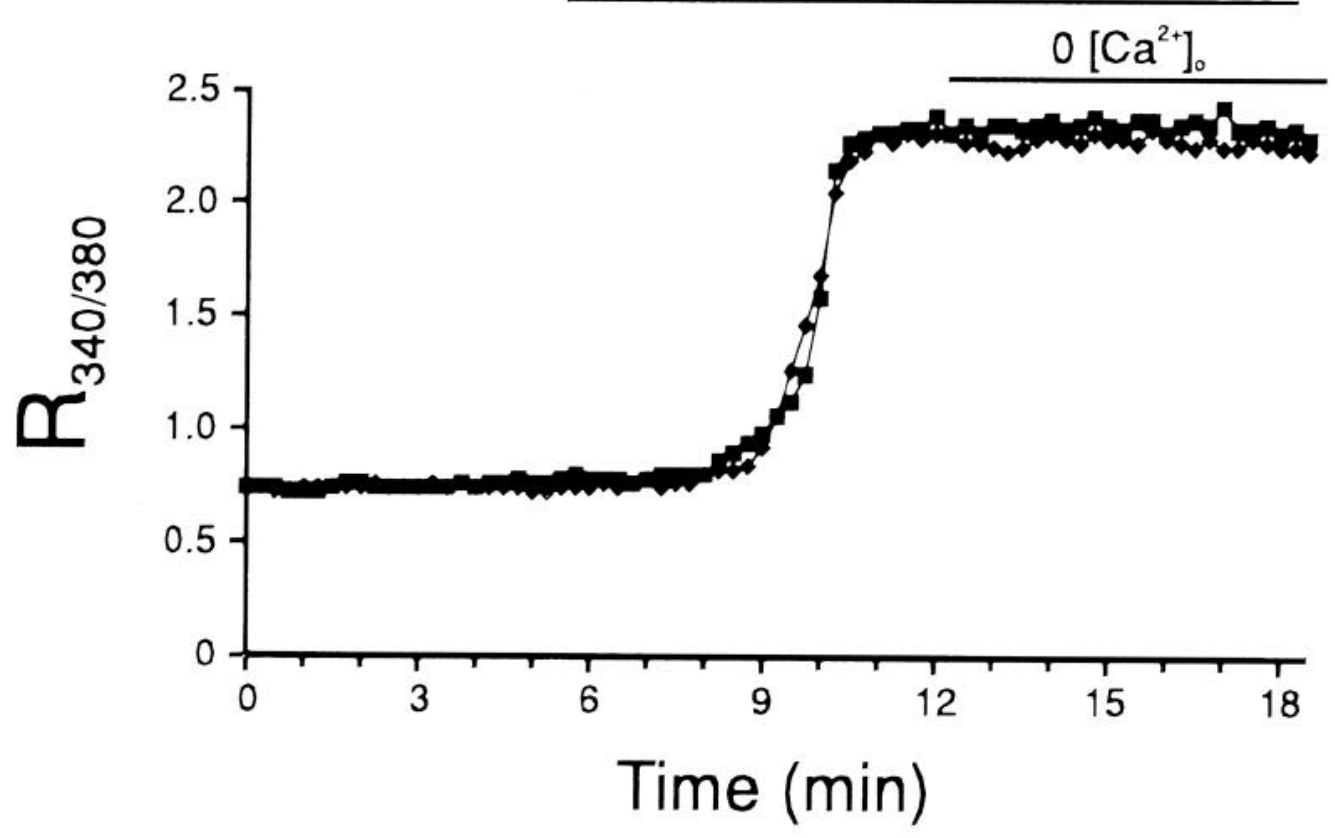

Figure 9. Hypoxia-hypoglycemia induced rapid $\left[\mathrm{Ca}^{2+}\right]_{\mathrm{i}}$ increases in Fura-2-loaded acutely isolated neurons, which were not reversed by removal of external $\left[\mathrm{Ca}^{2+}\right]_{\mathrm{o}} . A$, Fluorometric image of two closely spaced isolated pyramidal neurons. $B$, After 2.8 min of hypoxia-hypoglycemia, a rapid increase in basal $\left[\mathrm{Ca}^{2+}\right]_{\mathrm{i}}$ was initiated ( $\Delta R$ of 221 and $214 \%$ in these two cells), which was not reversed by removal of $\left[\mathrm{Ca}^{2+}\right]_{\mathrm{O}}$.

$\left[\mathrm{Ca}^{2+}\right]_{i}$ increases were observed in astrocytes even after very prolonged in vitro ischemia. It is reasonable, therefore, to speculate that the differences in viability of postischemic astrocytes and neurons relate to ischemic $\left[\mathrm{Ca}^{2+}\right]_{\mathrm{i}}$ metabolism. For example, $\left[\mathrm{Ca}^{2+}\right]_{\mathrm{i}}$ elevations in isolated ischemic astrocytes, but not in isolated neurons, were reversed by $\left[\mathrm{Ca}^{2+}\right]_{\mathrm{o}}$ removal. This suggests that neuronal $\mathrm{Ca}^{2+}$ efflux is markedly suppressed under hypoxic conditions, whereas astroglial $\mathrm{Ca}^{2+}$ extrusion is maintained at rates sufficient to buffer hypoxia-induced influx or release. Reduced neuronal $\mathrm{Ca}^{2+}$ efflux is likely given that the high density of voltage-gated $\mathrm{Na}$ channels and ionotropic transmitter receptors would result in intracellular $\mathrm{Na}^{+}$loading with subsequent suppression or reversal of $\mathrm{Ca}^{2+}$ extrusion via $\mathrm{Na}^{+}-\mathrm{Ca}^{2+}$ exchange. Differences in the nature of internal $\mathrm{Ca}^{2+}$ stores also may contribute. In addition to the inositol triphosphate-sensitive store common to both astrocytes and neurons, hippocampal neurons express a $\left[\mathrm{Ca}^{2+}\right]_{i}$-dependent $\mathrm{Ca}^{2+}$ release store (Simpson et al., 1995), which is either absent or of considerably lower capacity in astrocytes (Duffy and MacVicar, 1994b, 1995; Salter and Hicks, 1994). Thus, in neurons, $\mathrm{Ca}^{2+}$ influx may further augment $\mathrm{Ca}^{2+}$ release from internal stores leading to saturation of $\left[\mathrm{Ca}^{2+}\right]_{i}$ buffering mechanisms and subsequent activation of catabolic processes (i.e., activation of $\mathrm{Ca}^{2+}$-dependent proteases, lipases, and nucleases, and free-radical formation; for review, see Coyle and Puttfarcken, 1993).

\section{Astroglial $\left[\mathrm{Ca}^{2+}\right]_{\mathrm{i}}$ during pathological and nonpathological $\left[\mathrm{K}^{+}\right]_{0}$ elevations}

During spreading depression (SD) in vivo, $\left[\mathrm{K}^{+}\right]_{\mathrm{o}}$ can be elevated to levels (50-80 mu; Somjen, 1979) sufficient to increase astroglial $\left[\mathrm{Ca}^{2+}\right]_{i}$, as shown in this paper. SD also results in reactive transformation (Kraig et al., 1991), suggesting a link between these reactive responses and $\left[\mathrm{Ca}^{2+}\right]_{i}$ signaling. It has been pro- posed that SD is propagated by regenerative intercellular $\left[\mathrm{Ca}^{2+}\right]_{\mathrm{i}}$ waves through astrocyte networks (Nedergaard, 1994; Parpura et al., 1994). If this is the case, then the present results indicate that one source of $\left[\mathrm{Ca}^{2+}\right]_{\mathrm{i}}$ is voltage-dependent influx. In contrast, elevating $\left[\mathrm{K}^{+}\right]_{\mathrm{o}}$ to $15 \mathrm{~mm}$ did not increase $\left[\mathrm{Ca}^{2+}\right]_{\mathrm{i}}$. This result implies that $\left[\mathrm{K}^{+}\right]_{\mathrm{o}}$ elevations resulting from intense neuronal activity, which normally do not exceed a ceiling level of 8-12 mm (Somjen 1979), do not directly trigger voltage-dependent $\mathrm{Ca}^{2+}$ influx into astrocytes. Voltage-gated $\mathrm{Ca}^{2+}$ influx, therefore, is unique to pathological conditions associated with deregulation of $\left[\mathrm{K}^{+}\right]_{\mathrm{o}}$.

\section{Functional implications of astroglial $\left[\mathrm{Ca}^{2+}\right]_{\mathrm{i}}$ signaling during ischemia: possible roles in neuroprotection and neurotoxicity}

The rapid changes in astroglial physiology after reoxygenation and $\mathrm{SD}$, most notably a dramatic increase in protein synthesis (Gunn et al., 1990; Raley-Susman and Lipton, 1990; Petito et al., 1990; Bonthius and Steward, 1993; Hori et al., 1994), suggest the influence of early intracellular signals generated by these insults. Moreover, morphological transformation and proliferation, the hallmark reactive responses, can be initiated by stimuli that increase $\left[\mathrm{Ca}^{2+}\right]_{i}$ or stimulate $\left[\mathrm{Ca}^{2+}\right]_{i}$-sensitive enzymes (Harrison and Mobley, 1990; Puro and Mano, 1991; Yong, 1992), further supporting the involvement of $\left[\mathrm{Ca}^{2+}\right]_{\mathrm{i}}$ signaling in the initiation of reactive transformation.

Many postischemic responses could confer neuroprotection. Among the earliest ischemic responses is astrocytic swelling from $\mathrm{K}^{+}, \mathrm{Cl}^{-}$, and $\mathrm{Na}^{+}$uptake with obligatory water movement (Walz, 1989; Andrew and MacVicar, 1994; Landis, 1994). The ensuing regulatory volume decreases (RVDs) are dependent on increased $\left[\mathrm{Ca}^{2+}\right]_{\mathrm{i}}$ (Olson et al., 1990; Pierce and Politis, 1990; Bender and Norenberg, 1994) and subsequent activation of $\mathrm{Ca}^{2+}$-dependent 
A

Isolated Astrocyte


Isolated Astrocyte —_ Astrocyte in Slice . . . . .

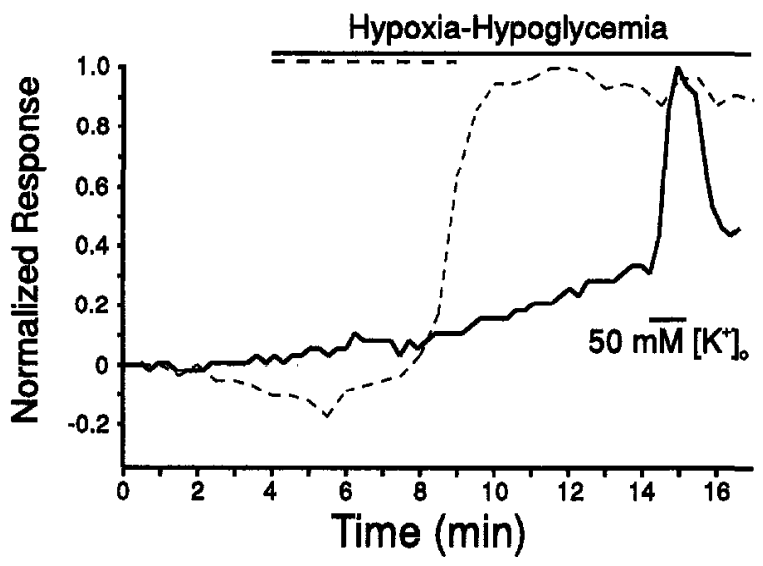

Figure 10. Comparison of ischemic $\left[\mathrm{Ca}^{2+}\right]_{\mathrm{i}}$ responses in coisolated hippocampal astrocytes and neurons $(A)$ and between astrocytes in slice and in isolation $(B)$. $A$, An acutely isolated astrocyte (trace marked $A$ ) and neuron (trace marked $N$ ) in the same field of view showed reversible $\left[\mathrm{Ca}^{2+}\right]_{\mathrm{i}}$ increases in response to multiple applications of $50 \mathrm{~mm}\left[\mathrm{~K}^{+}\right]_{\mathrm{o}}$ Subsequent hypoxia-hypoglycemia caused a rapid elevation in basal $\left[\mathrm{Ca}^{2+}\right]_{\mathrm{j}}$ in the neuron after $6.5 \mathrm{~min}(\Delta R$ of $239 \%)$, whereas astrocytic basal $\left[\mathrm{Ca}^{2+}\right]_{\mathrm{i}}$ was not significantly affected $(\Delta R$ of $10 \%$ after 10 min hypoxiahypoglycemia), $B$, A response, normalized to peak, from an astrocyte in slice (- . - - is superimposed onto a response from an isolated astrocyte $(-)$. After $5.5 \mathrm{~min}$ hypoxia-hypoglycemia, $\left[\mathrm{Ca}^{2+}\right]_{\mathrm{i}}$ of an astrocyte within a hippocampal slice rose rapidly to peak within 2 min (dashed bar). In contrast, $\left[\mathrm{Ca}^{2+}\right]_{i}$ of the isolated astrocyte did not increase markedly until the cell was depolarized by application of $50 \mathrm{mM}\left[\mathrm{K}^{+}\right]_{\mathrm{o}}$.

K channels (Quandt and MacVicar, 1986; Butt et al., 1990; Olson et al, 1990). Thus, one purpose for these $\left[\mathrm{Ca}^{2+}\right]_{i}$ transients might be to regulate volume recovery. This, in turn, could ameliorate neuronal pathology because astroglial swelling both directly causes the release of neurotoxic glutamate and aspartate (Kimelberg et al., 1990) and exacerbates the extracellular accumulation of excitotoxins by reducing the extracellular volume fraction (McBain et al., 1990). An interesting possibility is that swellinginduced activation of mechanosensitive Ca channels (Puro, 1991) or internal release (Charles et al., 1991) provides the RVD $\left[\mathrm{Ca}^{2+}\right]_{i}$ signal. However, cell swelling alone did not increase $\left[\mathrm{Ca}^{2+}\right]_{\mathrm{i}}$ in acutely isolated cells (Duffy and MacVicar, 1994b) or in intact slices. In addition, $\left[\mathrm{Ca}^{2+}\right]_{i}$ increases may reduce external glutamate through upregulation of glial glutamate transport (Flott and Seifert, 1991). Astroglial $\left[\mathrm{Ca}^{2+}\right]_{\mathrm{i}}$ signals also might trigger the release of auxiliary metabolites from astroglial glycogen stores (Phelps, 1972). Elevations in external $\left[\mathrm{K}^{+}\right]_{0}$ can trigger glyco- genolysis in both brain slices (Ververken et al., 1982; Hof et al., 1988) and cultured astrocytes (Cambray-Deakin et al., 1988). Loading of these stores can reduce neuronal death from hypoglyccmia in ncuron-astrocyte cocultures (Swanson and Choi, 1993) and possibly ischemic neuronal death in vivo (Swanson et al., 1990), whereas inhibition of glial glycogen synthesis or glucose uptake can potentiate hypoxic neuronal death in vitro (Virgin et al., 1991; Tombaugh et al., 1992). Finally, astroglial $\mathrm{Ca}^{2+}$ influx may reduce neurotoxicity simply by lowering $\left[\mathrm{Ca}^{2+}\right]_{0}$.

Although there is much circumstantial evidence for a neuroprotective function of astroglial $\left[\mathrm{Ca}^{2+}\right]_{i}$ increases, it is possible that, at least under some conditions, these signals are deleterious to ischemic astrocytes and ncurons. Prolonged ischemia (hours) in vitro does result in astroglial death, and this can be partially reversed by Ca channel antagonists (Yu et al., 1989; Haun et al., 1992). Also, $\mathrm{Ca}^{2+}$ deposits within mitochondria, a possible sign of cytotoxic $\left[\mathrm{Ca}^{2+}\right]_{\mathrm{i}}$ increases, have been observed in astrocytes after ischemia in vivo (Dux et al., 1987). Finally, the increase in $\left[\mathrm{K}^{+}\right]_{\mathrm{o}}$ and the decrease in $\left[\mathrm{Na}^{+}\right]_{0}$ associated with hypoxia can induce reverse glutamate transport (efflux) from glial cells (Szatkowski et al., 1990), which could exacerbate extracellular glutamate increases and contribute to ncuronal dcath (Szatkowski and Attwell, 1994). The recent demonstration of glutamate receptorcdependent $\left[\mathrm{Ca}^{2+}\right]_{i}$ signals in cultured neurons triggered by $\left[\mathrm{Ca}^{2+}\right]_{\mathrm{i}}$ waves through adjacent astrocytes (Parpura et al., 1994) suggests that astroglial glutamate efflux may be stimulated by $\left[\mathrm{Ca}^{2+}\right]_{\mathrm{i}}$.

Our results indicate that in response to ischemia, astrocytes exhibit a rise in $\left[\mathrm{Ca}^{2+}\right]_{i}$ mediated by voltage-dependent influx and release from internal stores. The role of these signals is a matter of conjecture. Elucidation of these postischemic signaling pathways has gained added significance with recent evidence, indicating that astrocytes can exert neuroprotective effects on neurons in some in vitro models of ischemia or glutamate toxicity (Vibulsreth et al., 1987; Nieto-Sampedro et al., 1988; Mattson and Rychlik, 1990; Petito et al., 1992; Vaca and Wendt, 1992; Hori et al., 1994). The possibility that these signals activate endogenous neuroprotective mechanisms is an important area for future research.

\section{REFERENCES}

Andrew RD, MacVicar BA (1994) Imaging cell volume changes and neuronal excitation in the hippocampal slice. Neuroscience 62:371-383.

Arslan P, Di Virgilio F, Deltrame M, Tsien RY, Pozzan T (1985) Cytosolic $\mathrm{Ca}^{2+}$ homeostasis in Ehrlich and Yoshida carcinomas: a new, membrane permeant chelator of heavy metals reveals that these ascites tumor cell lines have normal cytosolic free $\mathrm{Ca}^{2+}$. J Biol Chem 260:2719-2725.

Barres BA, Chun LLY, Corey DP (1989) Calcium current in cortical astrocytes: induction by cAMP and neurotransmitters and permissive effect of serum factors. J Neurosci 9:3169-3175.

Barres BA, Koroshetz WJ, Chun LLY, Corey DP (1990) Ion channel expression by white matter glia: the type-1 astrocyte. Neuron 5:527-544.

Bender AS, Norenberg MD (1994) Calcium dependence of hypoosmotically induced potassium release in cultured astrocytes. J Neurosci 14:4237-4243.

Bonthius DJ, Steward O (1993) Induction of cortical spreading depression with potassium chloride upregulates levels of messenger RNA for glial fibrillary acidic protein in cortex and hippocampus: inhibition by MK-801. Brain Res 618:83-94.

Butt AM, Hargittai PT, Lieberman EM (1990) Calcium-dependent regulation of potassium permeability in the glial perineurium (blood-brain barrier) of the crayfish. Neuroscience 38:175-185.

Cambray-Deakin M, Pearce B, Morrow C, Murphy S (1988) Effects of extracellular potassium on glycogen stores of astrocytes in vitro. $\mathrm{J}$ Neurochem 51:1846-1851. 
Charles AC, Merrill JE, Dirksen ER, Sanderson MJ (1991) Intracellular signalling in glial cells: calcium waves and oscillations in rcsponsc to mechanical stimulation. Neuron 6:983-992.

Choi D (1990) Cerebral hypoxia: some new approaches and unanswered questions. J Neurosci 10:2493-2501.

Clark GD, Rothman SM (1987) Blockade of excitatory amino acid receptors protects anoxic hippocampal slices. Neurosci 21:665-671.

Corvalan V, Cole R, de Vellis J, Hagiwara S (1990) Neuronal modulation of calcium channel activity in cultured rat astrocytes. Proc Natl Acad Sci USA 87:4345-4348.

Coyle JT, Puttfarcken P (1993) Oxidative stress, glutamate and neurodegenerative disorders. Science 262:689-695.

Duffy S, MacVicar BA (1993) Depolarization and $\alpha_{1}$-adrenergic stimulation of astrocytes in hippocampal slices evoke sustained increases and oscillations in cytosolic calcium. Soc Neurosci Abstr 19:688.

Duffy S, MacVicar BA (1994a) "In vitro ischemia" increases the $\left[\mathrm{Ca}^{2+}\right]$ of astrocytes within hippocampal slices. Soc Neurosci Abstr 20:1115.

Duffy S, MacVicar BA (1994b) Potassium-dependent calcium influx in acutely isolated hippocampal astrocytes. Neuroscience 61:51-61.

Duffy S, MacVicar BA (1995) Adrenergic calcium signalling in astrocyte networks within the hippocampal slice. J Neurosci 15:5535-5550.

Dux E, Mies G, Hossmann K-A, Siklos L (1987) Calcium in the mitochondria following brief ischemia of gerbil brain. Neurosci Lett 78:295-300.

Finkbeiner S (1993) Glial calcium. Glia 9:83-104.

Flott B, Seifert W (1991) Characterization of glutamate uptake systems in astrocyte primary cultures from rat brain. Glia 4:293-304.

Fraser DD, Duffy S, Angelides KJ, Perez-Velazquez JL, Kettenmann H,

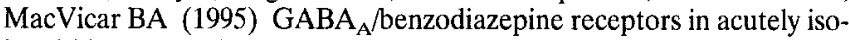
lated hippocampal astrocytes. J Neurosci 15:2720-2732.

Grigg JL, Anderson EG (1990) Competitive and noncompetitive $N$-methyl-D-aspartate antagonists modify hypoxia-induced membrane potential changes and protect rat hippocampal slices from functional failure: a quantitative comparison. J Pharmacol Exp Ther 253:130-135.

Gunn AJ, Dragunow M, Faull RLM, Gluckman PD (1990) Effects of hypoxia-ischemia and seizures on neuronal and glial-like c-fos protein levels in the infant rat. Brain Res 594:105-114.

Hanscn AJ (1985) Effects of anoxia on ion distribution in the brain. Physiol Rev 65:101-148.

Harrison BC, Mobley PL (1990) Phorbol ester-induced change in astrocyte morphology: correlation with protein kinase $\mathrm{C}$ activation and protein phosphorylation. J Neurosci Res 25:71-80.

Haun SE, Murphy EJ, Bates CM, Harrocks LA (1992) Extracellular calcium is a mediator of astroglial injury during combined glucoseoxygen deprivation. Brain Res 593:45-50.

Hof PR, Pascale F, Magistretti PJ (1988) $\mathrm{K}^{+}$at concentrations reached in the extracellular space during neuronal activity promotes $\mathrm{Ca}^{2+}$. dependent glycogen hydrolysis in mouse cerebral cortex. J Neurosci 8:1922-1928.

Hori O, Matsumoto M, Maeda Y, Ueda H, Ohtsuki T, Stern DM, Kinoshita T, Ogawa S, Kamada T (1994) Metabolic and biosynthetic alterations in cultured astrocytes exposed to hypoxia/reoxygenation. J Neurochem 62:1489-1495.

Katchman AN, Hershkowitz N (1993) Early anoxia-induced vesicular glutamate release results from mobilization of calcium from intracellular stores. J Neurophysiol 70:1-7.

Kimelberg HK, Goderie SK, Higman S, Pang S, Waniewski RA (1990) Swelling-induced release of glutamate, aspartate, and taurine from astrocyte cultures. J Neurosci 10:1583-1591.

Kim-Lee MH, Stokes BT, Yates AJ (1992) Reperfusion paradox: a novel model of glial cell injury. Glia 5:56-64.

Kraig RP, Dong L, Thisted R, Jeager CB (1991) Spreading depression increases immunohistochemical siaining of glial fibrillary acidic protein. J Neurosci 11:2187-2198.

Kraig RP, Jaeger CB (1990) Ionic concomitants of astroglial transformation to reactive species. Stroke 21:184-187.

Krnjevic K, Leblond J (1989) Changes in membrane currents of hippocampal neurons evoked by brief anoxia. J Neurophysiol 62:15-30.

Landis DMD (1994) The early reactions of non-neuronal cells to brain injury. Annu Rev Neurosci 17:133-151.

Lindsay RM (1986) Reactive gliosis. In: Astrocytes: cell biology and pathology of astrocytes (Fedoroff S, Vernadakis A, eds). New York: Academic.

Lobncr D, Lipton P (1993) Intracellular calcium levels and calcium fluxes in CAl region of the rat hippocampal slice during in vitro ischemia: relationship to electrophysiological cell damage. $J$ Neurosci 13:4861-4871.

MacVicar BA (1984) Voltage-dependent calcium channels in glial cells. Science 226:1345-1347.

Martin RL, Lloyd HGE, Cowan AI (1994) The early events of oxygen and glucose deprivation: setting the scene for neuronal death? Trends Neurosci 17:251-257.

Mattson MP, Rychlik B (1990) Glia protect hippocampal neurons against excitatory amino acid-induced degeneration: involvement of fibroblast growth factor. Int J Dev Neurosci 8:399-415.

McBain CJ, Traynellis SF, Dingledine R (1990) Regional variation of extracellular space in the hippocampus. Science 249:674-677.

Mitani A, Yanase H, Sakai K, Wake Y, Kataoka K (1993) Origin of intracellular $\mathrm{Ca}^{2+}$ elevation induced by in vitro ischemia-like condition in hippocampal slices. Brain Res 601:103-110.

Nedergaard M (1994) Direct signaling from astrocytes to neurons in cultures of mammalian brain cells. Science 263:1768-1771.

Nicotera P, Bellomo G, Orrenius S (1992) Calcium-mediated mechanisms in chemically induced cell death. Annu Rev Pharmacol Toxicol $32: 449-470$.

Nieto-Sampedro M, Lim R, Hicklin DJ, Cotman CW (1988) Early release of glial maturation factor and acid fibroblast growth factor after rat brain injury. Neurosci Lett 86:361-365.

Olson JE, Fleischhacker D, Murray WB, Holtzman D (1990) Control of astrocyte volume by intracellular and extracellular $\mathrm{Ca}^{2+}$. Glia 3:405-412.

Orrenius S, McConkey DJ, Bellomo G, Nicotera P (1989) Role of $\mathrm{Ca}^{2+}$ in toxic cell killing. Trends Pharmacol Toxicol 10:281-285.

Parpura V, Basarsky TA, Liu F, Jeftinija K, Jeftinija S, Haydon PG (1994) Glutamate-mediated astrocyte-neuron signalling. Nature 369:744-747.

Petito CK, Chung MC, Verkhovsky LM, Cooper AJLP (1992) Brain glutamine synthetase increases following cerebral ischemia in the rat. Brain Res 569:275-280.

Petito CK, Morgello S, Felix JC, Lesser ML (1990) The two patterns of reactive astrocytosis in postischemic rat brain. $\mathbf{J}$ Cereb Blood Flow Metab 10:850-859.

Phelps CH (1972) Barbiturate-induced glycogen accumulation in brain: an electron microscopic study. Brain Res 39:225-234.

Pierce SK, Politis AD (1990) Calcium-activated ccll volumc recovery mechanisms. Annu Rev Physiol 52:27-42.

Pope A (1978) Neuroglia: quantitative aspects. In: Dynamic properties of glial cells (Frank G, Hertz L, Schotteneils E, Tower DB, eds), pp 13-20. New York: Pergamon.

Pozzan T, Rizzuto R, Volpe P, Meldolesi PJ (1994) Molecular and cellular physiology of intracellular calcium stores. Physiol Rev 74:595-636.

Puro DG (1991) Stretch-activated channels in human retinal muller cells. Glia 4:456-460.

Puro DG, Mano T (1991) Modulation of calcium channels in human retinal glial cells by basic fibroblast growth factor: a possible role in retinal pathobiology. J Neurosci 11:1873-1880.

Quandt FN, MacVicar BA (1986) Calcium activated potassium channels in cultured astrocytes. Neuroscience 19:29-41.

Rader RK, Lanthorn TH (1989) Experimental ischemia induces a persistent depolarization blocked by decreased calcium and NMDA antagonists. Neurosci Lett 99:125-130.

Raley-Susman K, Lipton P (1990) In vitro ischemia and protein synthesis in the rat hippocampal slice: the role of calcium and NMDA receptor activation. Brain Res 515:27-38.

Reier PJ (1986) Gliosis following CNS injury: the anatomy of astrocytic scars and their influences on axonal elongation. In: Astrocytes: cell biology and pathology of astrocytes (Fedoroff S, Vernadakis A, eds), New York: Academic.

Salter MW, Ilicks JL (1994) ATP-evoked increases in intracellular calcium in neurons and glia from the dorsal spinal cord. J Neurosci $14: 1563-1575$.

Siesjo BK, Bengtsson F (1989) Calcium fluxes, calcium antagonists, and calcium-related pathology in brain ischemia, hypoglycaemia, and spreading depression: a unifying hypothesis. J Cereb Blood Flow Metab $9: 127-140$.

Silver IA, Erecinska M (1990) Intracellular and extracellular changes of $\left[\mathrm{Ca}^{2+}\right]$ in hypoxia and ischemia in rat brain in vivo. $\mathrm{J}$ Gen Physiol 95:837-866. 
Simpson PB, Challiss RAJ, Nahorski SR (1995) Neuronal $\mathrm{Ca}^{2+}$ stores: activation and function. Trends Neurosci 18:299-306.

Somjen GG (1979) Extracellular potassium in the mammalian central nervous system. Annu Rev Physiol 41:159-177.

Swanson RA, Choi DW (1993) Glial glycogen stores affect neuronal survival during glucose deprivation in vitro. J Cereb Blood Flow Metab 13:162-169.

Swanson RA, Shiraishi K, Morton MT, Sharp FR (1990) Methionine sulfoximine reduces cortical infarct size in rats after middle cerebral artery occlusion. Stroke 21:322-327.

Szatkowski M, Attwell D (1994) Triggering and execution of neuronal death in brain ischaemia: two phases of glutamate release by different mechanisms. Trends Neurosci 17:359-365.

Szatkowski M, Barbour B, Attwell D (1990) Non-vesicular release of glutamate from glial cells by reversed electrogenic glutamate uptake. Nature 348:443-446.

Tombaugh GC, Yang SH, Swanson RA, Sapolsky RM (1992) Glucocorticoids exacerbate hypoxic and hypoglycaemic hippocampal injury in vitro: biochemical correlates and a role for astrocytes. $J$ Neurochem 59:137-146.

Vaca K, Wendt E (1992) Divergent effects of astroglial and microglial secretions on neuron growth and survival. Exp Neurol 118:62-72.

Ververken D, Van Veldhoven P, Proost C, Carton H, De Wulf H (1982)
On the role of calcium ions in the regulation of glycogenolysis in mouse brain cortical slices. J Neurochem 38:1286-1295.

Vibulsreth S, Hefti F, Ginsberg MD, Dietrich WD, Busto R (1987) Astrocytes protect cultured neurons from degeneration induced by anoxia. Brain Res 422:303-311.

Virgin CE, Ha TP, Packan DR, Tombaugh GG, Yang SH, Horner HC, Sapolsky RM (1991) Glucocorticoids inhibit glucose transport and glutamate uptake in hippocampal astrocytes: implications for glucocorticoid neurotoxicity. J Neurochem 57:1422-1480.

Walz W (1989) Role of glial cells in the regulation of the brain ion microenvironment. Prog Neurobiol 33:309-333.

Waxman SG, Ransom BR, Stys PK (1991) Non-synaptic mechanisms of $\mathrm{Ca}^{2+}$-mediated injury in $\mathrm{CNS}$ white matter. Trends Neurosci $14: 461-468$.

Yong VW (1992) Proliferation of human and mouse astrocytes in vitro: signalling through the protein kinase $\mathrm{C}$ pathway. J Neurol Sci 111:92-103.

Young JN, Somjen GG (1992) Suppression of presynaptic calcium currents by hypoxia in hippocampal tissue slices. Brain Res $573: 70-76$.

Yu ACH, Gregory GA, Chan PH (1989) Hypoxia-induced dysfunctions and injury of astrocytes in primary culture. J Cereb Blood Flow Metab 9:20-28. 